\title{
PENGEMBANGAN LEMBAR KERJA SISWA BANGUN RUANG SISI DATAR DENGAN PENDEKATAN KONTEKSTUAL BERMUATAN NILAI KARAKTER
}

(Development Polyhedron Student's Worksheet using Contextual Approach to the Value of Character)

\author{
Rahmatya Nurmeidina \\ Program Studi Pendidikan Matematika, Fakultas Keguruan dan IImu Pendidikan \\ Universitas Muhammmadiyah Banjarmasin \\ Email: rahmatya.dina@umbjm.ac.id
}

\begin{abstract}
ABSTRAK
Pembelajaran matematika yang berhasil didukung oleh perangkat pendukung pembelajaran yang baik, seperti Lembar Kerja Siswa (LKS). Penelitian ini bertujuan untuk mengembangkan LKS Bangun Ruang Sisi Datar dengan pendekatan kontekstual yang valid dan praktis. LKS ini juga dilengkapi dengan muatan nilai karakter seperti nilai kerja sama, kerja keras, rasa ingin tahu dan peduli. Penelitian ini merupakan penelitian pengembangan dengan menggunakan model pengembangan Thiagharajan, Dorothy S. Semmel dan Melvyn I Semmel. Hasil penelitian menunjukkan bahwa aspek kevalidan LKS ditinjau dari penilaian para ahli dan mencapai kategori valid, dan aspek kepraktisan LKS mencapai kategori sangat praktis ditinjau penilaian oleh guru dan praktis jika ditinjau dari penilaian oleh siswa.
\end{abstract}

Kata kunci : pengembangan, Lembar Kerja Siswa (LKS), Bangun Ruang Sisi Datar, Pendekatan Kontekstual, nilai karakter

\section{ABSTRACT}

Successful mathematics learning is supported by good learning support devices, such as Student Worksheets (LKS). This study aims to develop polyhedron student's worksheet with contextual approach which is valid and practical. This LKS is also equipped with the contents of character values such as the value of cooperation, hard work, curiosity and caring. This research is a development research using the development model of Thiagharajan, Dorothy S. Semmel and Melvyn I Semmel. The results showed that the validity aspect of the worksheet was viewed from the experts' judgment and reached a valid category, and the practical aspects of the worksheet reached a very practical category reviewed by the teacher's assessment and reached a practical category when viewed from the assessment by students.

Keywords : development, student's worksheet (LKS), polyhedron, contextual approach, value of character

\section{PENDAHULUAN}

Standar proses pembelajaran dijelaskan dalam Permendiknas No.68 tahun 2013 tentang standar proses yang menyebutkan bahwa kompetensi inti meliputi menghargai dan menghayati ajaran agama yang dianutnya, menghargai dan menghayati perilaku jujur, disiplin, tanggung jawab, peduli (toleransi, gotong royong), santun, percaya diri, dalam berinteraksi secara efektif dengan lingkungan sosial dan alam dalam jangkauan pergaulan dan keberadaannya, memahami pengetahuan (faktual, konseptual, dan prosedural) berdasarkan rasa ingin tahunya tentang ilmu pengetahuan, teknologi, seni, budaya terkait fenomena dan kejadian tampak mata, mencoba, mengolah, dan menyaji dalam ranah konkret (menggunakan, mengurai, merangkai, memodifikasi, dan membuat) dan ranah abstrak (menulis, membaca, menghitung, menggambar, dan mengarang) sesuai dengan yang dipelajari di sekolah dan sumber lain yang sama dalam sudut pandang/teori.

Dalam kaitannya dengan penjelasan di atas standar proses pembelajaran diantaranya 
memahami pengetahuan dan juga mengembangkan karakter siswa seperti jujur, disiplin, tanggun jawab, peduli, percaya diri, rasa ingin tahu. Untuk mengembangkan karakter tersebut diperlukan pembelajaran yang terintegrasi dengan muatan nila-nilai karakter. Karakter memiliki tiga bagian yang saling berhubungan yaitu pengetahuan moral, perasaan moral, dan perilaku moral. Karakter yang baik terdiri dari mengetahui yang baik, menginginkan yang baik, dan melakukan kebiasaan baik dari pikiran, kebiasaan hati, dan kebiasaan tindakan. Ketiganya diperlukan untuk memimpin kehidupan moral dan membentuk kematangan moral (Lickona, 2009; Kemdiknas, 2011).

Pembelajaran matematika SMP memiliki standar kompetensi yang harus dimiliki siswa, salah satunya geometri. Geometri SMP termuat dalam pokok bahasan bangun Ruang Sisi Datar dan merupakan salah satu kategori kemampuan yang diujikan dalam ujian nasional. Oleh karena itu, pokok bahasan ini penting untuk dipahami dengan baik oleh siswa. Berdasarkan data Ujian Nasional tahun 2013 tentang daya serap siswa untuk diperoleh informasi bahwa pokok bahasan kemampuan memahami sifat dan unsur bangun ruang dan menggunakannya dalam pemecahan masalah menempati posisi paling rendah dari 6 kemampuan yang diujikan. Untuk mengatasi masalah ini, guru diharapkan dapat mengaitkan pembelajaran dengan kehidupan sehari-hari agar siswa dapat memahami konsep dengan mudah, sehingga prestasi belajarnya dapat meningkat.

Pembelajaran di sekolah masih cenderung belum mengaitkan pembelajaran yang dipelajari di kelas dengan masalah yang berkaitan dengan kehidupan sehari-hari. Sutama \& Putro (2013) menyatakan bahwa berdasarkan pengamatan awal, pembelajaran matematika di Sekolah Menengah Pertama (SMP) cenderung text book oriented dan kurang terkait dengan kehidupan sehari-hari siswa. Pembelajaran cenderung abstrak, sehingga konsep-konsep akademik sulit dipahami.

Dengan demikian diperlukan usaha oleh guru untuk menyusun pembelajaran yang tidak hanya membuat siswa memahami konsep materi saja, tetapi juga dapat mengaitkan pembelajaran yang dipelajari di kelas dengan masalah yang berkaitan dengan kehidupan sehari-hari, sekaligus memberikan penanaman nilai karakter dalam pembelajaran. Pembelajaran tersebut dapat terlaksana salah satunya dengan memilih pendekatan pembelajaran yang tepat, salah satu pendekatan tersebut adalah, pendekatan kontekstual.

Pendekatan Kontekstual adalah pendekatan pembelajaran yang mengaitkan materi yang dipelajari dengan kehidupan sehari-hari, keadaan pribadi, sosial dan lingkungan di sekitar siswa, sehingga siswa merasakan bahwa pelajaran yang mereka pelajari bermanfaat bagi kehidupan. (Johnson, 2009; Nurhadi, 2002). Pendekatan kontekstual mempunyai tujuh komponen utama, yakni konstruktivisme (constructivism), penemuan (inquiry), bertanya (questioning), masyarakat belajar (learning community), pemodelan (modeling), refleksi (reflection), dan penilaian yang sebenarnya (authentic assessment) (Nurhadi, 2002). Pendekatan kontekstual yang digunakan dalam pembelajaran diharapkan dapat pula mengembangkan nilai pendidikan karakter. Adapun nilai pendidikan karakter yang penting dikembangkan dalam pembelajaran matematika menurut Kemdiknas (2010) antara lain adalah kerja keras, rasa ingin tahu, kerja sama dan peduli. Pembelajaran dengan pendekatan kontekstual ini perlu didukung oleh bahan belajar yang digunakan di kelas, salah satunya melalui LKS yang digunakan guru dan siswa dalam pembelajaran di kelas. LKS yang disusun dapat dirancang dan dikembangkan sesuai dengan kondisi dan situasi kegiatan pembelajaran yang akan dihadapi (Widjajanti, 2008). Untuk itu, guru sebagai pengajar dikelas dapat menyusun LKS dengan menggunakan pendekatan kontekstual dan juga memuat nilai pendidikan karakter.

Berdasarhasil survey yang dilakukan pada guru pengajar matematika SMP, guru tersebut belum membuat dan menggunakan LKS yang memuat pendidikan karakter dalam pembelajaran. Hal yang senada juga diperoleh dari hasil prasurvei Sanjaya (2012) yang dilakukan pada enam SMP, diperoleh data bahwa ketersediaan perangkat dan sumber belajar terutama Lembar Kegiatan Siswa (LKS) yang menunjang nilai-nilai karakter sangatlah terbatas. Selain informasi tersebut, berdasarkan hasil prasurvey dengan wawancara guru dan pengamatan juga diketahui bahwa siswa enggan belajar jika tidak ada PR, siswa enggan belajar terlebih dahulu jika materi tersebut belum diajarkan di sekolah, hanya senang mengerjakan soal-soal yang mudah saja, dan kurang terlibat aktif jika belajar dalam kelompok. Hal ini menandakan bahwa nilai karakter kerja keras, rasa ingin tahu dan kerja sama dalam proses pembelajaran di sekolah masih kurang dimiliki oleh siswa. 
Dengan demikian diperlukan penelitian untuk mengembangkan LKS bangun ruang sisi datar dengan pendekatan kontekstual bermuatan nilai pendidikan karakter.

\section{METODE PENELITIAN}

Penelitian ini merupakan penelitian pengembangan dengan menggunakan model pengembangan Thiagharajan, Dorothy S. Semmel dan Melvyn I Semmel yang terdiri dari empat tahapan yaitu define, design, development, dan dissemination (Thiagarajan, Semmel \& Semmel, 1974). Subjek penelitian pada uji coba terbatas adalah 9 orang siswa SMP. Subjek penelitian pada uji coba lapangan adalah 34 orang siswa kelas 8 SMP dan 1 orang guru matematika SMP yang mengajar siswa tersebut.

Prosedur pengembangan yang dilakukan peneliti meliputi proses define, design dan development. Tahap pertama adalah Define (pendefinisian), tujuan tahap ini adalah menentukan dan mendefinisikan syarat-syarat pembelajaran. Pada tahap ini dilakukan beberapa hal yaitu analisis awal akhir, analisis siswa, analisis materi, analisis tugas, dan spesifikasi tujuan pembelajaran. Berdasarkan tahap pendefinisian maka direncanakan pengembangan LKS bangun ruang sisi datar dengan pendekatan kontekstual bermuatan nilai karakter.

Tahap kedua adalah tahap perancangan (design). Tujuan tahap ini adalah merancang perangkat pembelajaran dan instrument penelitian. Kegiatan utama yang dilakukan pada tahap ini adalah mengkonstruksi tes menggunakan acuan kategori, pemilihan media, pemilihan format, dan perancangan awal. Produk yang didesain adalah LKS bangun ruang sisi datar dengan pendekatan kontekstual bermuatan nilai karakter.

Tahap ketiga adalah tahap pengembangan (develop). Tujuan tahap ini adalah untuk menghasilkan LKS yang valid dan praktis. Pada tahap ini dilakukan proses validasi ahli, uji coba terbatas, dan uji coba lapangan. Proses validasi dinilai oleh 3 orang ahli pendidikan matematika. Selanjutnya peneliti memperbaiki LKS sesuai dengan saran perbaikan dari validator. LKS yang sudah diperbaiki kemudian dilakukan uji coba terbatas. Uji coba terbatas dilakukan dengan menggunakan panduan keterbacaan yang diisi oleh siswa. Setelah proses ini, LKS kembali diperbaiki sesuai dengan hasil dari uji coba keterbacaan. Selanjutnya, Uji coba lapangan dilaksanakan untuk mengetahui bagaimana kepraktisan LKS yang dikembangkan.

Instrumen dan Teknik Pengumpulan Data

Teknik pengumpulan data untuk penilaian validasi ahli adalah ahli melakukan penilaian dengan mengisi instrumen lembar validasi ahli yang telah disusun sesuai dengan indikator validitas ahli yang terdiri dari 4 aspek yaitu kesesuaian isi dan materi, kesesuaian dengan syarat konstruksi, kesesuaian dengan syarat teknis dan pengembangan karakter. Sedangkan, teknik pengumpulan data untuk mengukur kepraktisan LKS yang dikembangkan adalah dengan menggunakan lembar penilaian kepraktisan oleh guru dan lembar penilaian kepraktisan oleh siswa yang telah disusun sesuai dengan indikator penilaian kepraktisan, yaitu kemudahan keterbacaan isi LKS, kemudahan memahami isi dan penjelasan LKS dan keterkaitan isi LKS dengan nilai karakter.

Teknik Analisis Data

Data kualitatif berupa hasil pengisian lembar validasi, lembar penilaian kepraktisan oleh guru dan lembar penilaian kepraktisan oleh siswa diklasifikasikan menjadi 5 kategori pilihan dengan rentang skala penilaian 5 yaitu skor 1 , skor 2 , skor 3 , skor 4, dan skor 5 . Teknik analisis data dengan 5 kategori pilihan yaitu dengan mengelompokkan data berdasarkan kualifikasi produk yang akan dinilai. Berdasarkan data yang telah dikelompokkan kemudian dilakukan perhitungan untuk memperoleh nilai rata-rata. Untuk menghitung rata-rata menggunakan acuan sebagai berikut:

Keterangan: Keterangan:

$\bar{x}=\frac{\Sigma x}{n}$

$\bar{x}=$ skor rata-rata

$\Sigma x=$ total skor jawaban

$\mathrm{N}$ = banyak evaluator

Skor rata-rata yaıry uiveıvieı neııludian dimasukkan kedalam kategori kualitatif yang diadaptasi dari Azwar (2009). Adapun tabel kategori penilaian skala likert untuk penilaian kevalidan adalah sebagai berikut:

Tabel 1. Kategori Penilaian Kevalidan

\begin{tabular}{cc}
\hline Interval Skor & Nilai \\
\hline $\bar{x}>72$ & $\mathrm{~A}$ \\
$60<\bar{x} \leq 72$ & $\mathrm{~B}$ \\
$48<\bar{x} \leq 60$ & $\mathrm{C}$ \\
$36<\bar{x} \leq 48$ & $\mathrm{D}$ \\
$\bar{x} \leq 36$ & $\mathrm{E}$ \\
\hline
\end{tabular}


LKS dikatakan valid jika memenuhi kategori minimal B. Sedangkan penilaian kepraktisan terdiri dari dua penilaian, yaiu penilaian kepratisan oleh guru dan penilaian kepraktisan oleh siswa. Adapun kategori penilaian kepraktisan oleh guru disajikan pada tabel berikut:

Tabel 2. Kategori Penilaian Kepraktisan oleh guru

\begin{tabular}{cc}
\hline Interval Skor & Nilai \\
\hline $\bar{x}>32$ & $\mathrm{~A}$ \\
$26,67<\bar{x} \leq 32$ & $\mathrm{~B}$ \\
$21,33<\bar{x} \leq 26,67$ & $\mathrm{C}$ \\
$16<\bar{x} \leq 21,33$ & $\mathrm{D}$ \\
$\bar{x} \leq 16$ & $\mathrm{E}$ \\
\hline
\end{tabular}

Sedangkan kategori penilaian kepraktisan oleh siswa disajikan pada tabel berikut.

Tabel 3. Kategori Penilaian Kepraktisan siswa

\begin{tabular}{cc}
\hline Interval Skor & Nilai \\
\hline $\bar{x}>36$ & $\mathrm{~A}$ \\
$30<\bar{x} \leq 36$ & $\mathrm{~B}$ \\
$24<\bar{x} \leq 30$ & $\mathrm{C}$ \\
$18<\bar{x} \leq 24$ & $\mathrm{D}$ \\
$\bar{x} \leq 18$ & $\mathrm{E}$ \\
\hline
\end{tabular}

Kategori kualitatif yang digunakan pada lembar penilaian guru dan lembar penilaian siswa adalah sangat praktis (A), praktis (B), cukup praktis (C), kurang praktis $(D)$ dan sangat kurang praktis $(E)$.

\section{HASIL DAN PEMBAHASAN}

Hasil pengembangan pada penelitian ini adalah LKS bangun ruang sisi datar dengan pendekatan kontekstual bermuatan nilai karakter. Masalah, gambar dan ilutrasi mengenai materi yang akan diajarkan disesuaikan dengan konteks dunia nyata dan dikaitkan dengan pengembangan nilai karakter misalnya pada materi unsur-unsur bangun ruang dikaitkan dengan pembuatan kotak pensil berbentuk kubus dengan mengunakan kertas bekas yan dikaitkan dengan kepedulian terhadap lingkungan. Pada LKS juga diberikan kalimat motivasi yang bermuatan nilai pendidikan karakter kerja keras, kerja sama dan rasa ingin tahu. Struktur LKS terdiri dari judul, kompetesi dasar, kolom nama anggota kelompok, indikator, petunjuk, permasalahan atau ilustrasi cerita yang sesuai dengan kehidupan sehari-hari, langkahlangkah kerja, tugas dan latihan. LKS ini terdiri dari
8 LKS. LKS 1 dan 2 dengan materi menyebutkan bagian-bagian kubus, balok, prisma, dan limas : rusuk, bidang sisi, diagonal bidang, diagonal ruang, bidang diagonal. LKS 3 dan 4 dengan materi membuat jaring-jaring kubus, balok, prisma tegak dan limas. LKS 5 dan 6 dengan materi menemukan rumus dan menghitung luas permukaan kubus, balok, prisma tegak dan limas. LKS 7 dan 8 dengan materi menentukan dan menghitung rumus volum kubus, balok, prisma tegak dan limas.

Hasil analisis kevalidan LKS oleh 3 orang ahli disajikan pada tabel berikut ini.

Tabel 4. Hasil Analisis kevalidan LKS oleh Ahli

\begin{tabular}{cc}
\hline Interval Skor & Nilai \\
\hline 1 & 75 \\
2 & 72 \\
3 & 83 \\
Skor Total & 230 \\
Rata-rata & 76,67 \\
Kriteria & $\mathrm{A}$ \\
\hline
\end{tabular}

Berdasarkan hasil analisis validasi LKS dari tabel 4 menunjukkan bahwa setiap aspek yang dinilai berada pada kategori A, sehingga dapat disimpulkan bahwa LKS yang dikembangkan valid.

Penilaian kepraktisan dari LKS yang dikembangkan diketahui dari analisis hasil lembar penilaian kepraktisan oleh guru dan lembar penilaian kepraktisan oleh siswa. Berikut ini hasil analisis penilaian perangkat pembelajaran oleh guru yang disajikan pada tabel 5 .

Tabel 5. Penilaian kepraktisan LKS oleh Guru.

\begin{tabular}{cc}
\hline Guru & Skor Penilaian LKS \\
\hline 1 & 35,25 \\
Kategori & $\mathrm{A}$ \\
\hline
\end{tabular}

Hasil analisis pada tabel 5 menunjukkan bahwa kepraktisan LKS mendapatkan skor 35,25. Total skor ini termasuk dalam kategori $A$, sehingga dapat disimpulkan bahwa LKS yang dikembangkan menurut penilaian kepraktisan oleh guru adalah sangat praktis. Berikut ini hasil analisis penilaian kepraktisan LKS oleh siswa.

Tabel 6. Penilaian Kepraktisan LKS oleh siswa

\begin{tabular}{ccc}
\hline Siswa & $\begin{array}{c}\text { Jumlah } \\
\text { Siswa }\end{array}$ & $\begin{array}{c}\text { Skor } \\
\text { Penilaian } \\
\text { LKS }\end{array}$ \\
\hline Rata-rata & 34 & \multicolumn{2}{c}{1186} \\
Kategori & \multicolumn{2}{c}{34,88} \\
B \\
\hline
\end{tabular}


Tabel 6 di atas menunjukkan bahwa skor rata-rata penilaian siswa terhadap LKS adalah 34,88. Total skor ini termasuk dalam kategori $\mathrm{B}$, sehingga dapat disimpulkan bahwa LKS yang dikembangkan menurut penilaian kepraktisan oleh siswa berada pada kategori praktis.

\section{KESIMPULAN}

Keimpulan dari penelitian ini adalah sebagai berikut.

1. Aspek kevalidan LKS ditinjau dari penilaian para ahli mencapai kategori sangat valid,

2. Aspek kepraktisan LKS ditinjau dari penilaian oleh guru mencapai kategori sangat praktis dan aspek kepraktisan LKS ditinjau dari penilaian siswa mencapai kategori praktis.

Dengan demikian dapat disimpulkan bahwa LKS Bangun Ruang sisi datar dengan pendekatan Kontekstual bermuatan nilai karakter valid dan praktis untuk digunakan. Adapun saran untuk penelitian ini adalah LKS dengan pendekatan Kontekstual bermuatan nilai karakter dapat dikembangkan untuk materi atau pokok bahasan matematika yang lain.

\section{DAFTAR PUSTAKA}

Azwar, S. (2009). Tes prestasi: Fungsi dan pengembangan pengukuran prestasi belajar. Yogyakarta: Pustaka Pelajar.

Johnson, E. B. (2009). Contextual teaching and learning: What it is and why it's here to stay. Corwin Press. (Terjemahan A. Chaedar Alwasilah)

Kemdiknas, T. P. (2011). Panduan Pelaksanaan Pendidikan Karakter. Jakarta: Pusat Kurikulum dan Perbukuan, Badan Penelitian dan Pengembangan, Kemendiknas.

Lickona, T. (2009). Educating for character: How our schools can teach respect and responsibility. Bantam.
Nurhadi. (2002). Pendekatan kontekstual. Jakarta : Depdikbud

Pendidikan, P. M., \& Nomor, K. (68). Tahun 2013 tentang Kerangka Dasar dan Struktur Kurikulum Sekolah Menengah Pertama. Madrasah Tsanawiyah.

Peraturan Menteri Pendidikan dan Kebudayaan Republik Indonesia (Permendikbud) No.68 Tahun 2013. Kerangka Dasar dan Struktur Kurikulum Sekolah Menengah Atas dan Madrasah Aliyah.

Kementerian Pendidikan Nasional. 2010. Bahan Pelatihan Penguatan Metodologi PembelajaranBerdasarkan Nilai-Nilai Budaya Untuk Membentuk Daya Saing dan Karakter Bangsa. Jakarta:Pusat Kurikulum, Badan Penelitian dan Pengembangan.

Sanjaya, T. M. (2012). Pengembangan perangkat pembelajaran matematika SMP yang mennjang pendidikan karakter. Tesis magister, tidak diterbitkan, UNY, Yogyakarta.

Sutama, S., \& Putro, K. I. R. S. (2013). Pengelolaan Pembelajaran Matematika Sekolah Standar Nasional. Delta Jurnal IImiah Pendidikan Matematika FKIP Universitas Pekalongan, 1(1).

Thiangarajan S., Semmel D \& Semmel M. I (1974). Instructional development for training teachers of exceptional Children: $A$ sourcebook. Minnesota: Central for Innovation on teaching the handicaved.

Widjajanti, E. (2008). Kualitas lembar kerja siswa. In Makalah Seminar Pelatihan penyusunan LKS untuk Guru SMK/MAK pada Kegiatan Pengabdian Kepada Masyarakat Jurusan Pendidikan FMIPA Universitas Negeri Yogyakarta (pp. 2-5). 